\title{
Culturable endophytic bacteria associated with medicinal plant Ferula songorica: molecular phylogeny, distribution and screening for industrially important traits
}

\author{
Yong-Hong Liu ${ }^{1,2,5} \cdot$ Jian-Wei Guo ${ }^{1,3} \cdot$ Nimaichand Salam ${ }^{2} \cdot \mathrm{Li} \mathrm{Li}^{1}$ • \\ Yong-Guang Zhang ${ }^{1} \cdot$ Jian Han $^{1,5} \cdot$ Osama Abdalla Mohamad ${ }^{1,4} \cdot$ Wen-Jun $\mathrm{Li}^{1,2}$
}

Received: 15 June 2016/Accepted: 14 September 2016/Published online: 28 September 2016

(c) The Author(s) 2016. This article is published with open access at Springerlink.com

\begin{abstract}
Xinjiang, a region of high salinity and drought, is a host to many arid and semi-arid plants. Many of these plants including Ferula spp. have indigenous pharmaceutical histories. As many of the medicinal properties of plants are in tandem with the associated microorganisms residing within the plant tissues, it is advisable to explore the endophytic potential of such plants. In the present study, diversity of culturable bacteria isolated from medicinal plants Ferula songorica collected from Hebukesaier, Xinjiang were analyzed. A total of 170 endophytic bacteria belonging to three phyla, 15 orders, 20 families and 27 genera were isolated and characterized by $16 \mathrm{~S}$ rRNA gene sequencing. The phylum Actinobacteria constitutes a major portion of the endophytic microbes isolated from the plant Ferula songorica (107 isolates).
\end{abstract}

Wen-Jun Li

liwenjun3@mail.sysu.edu.cn

1 Key Laboratory of Biogeography and Bioresource in Arid Land, Xinjiang Institute of Ecology and Geography, Chinese Academy of Sciences, Urümqi 830011, Xinjiang,

People's Republic of China

2 State Key Laboratory of Biocontrol and Guangdong Provincial Key Laboratory of Plant Resources, School of Life Sciences, Sun Yat-Sen University, Guangzhou 510275, People's Republic of China

3 Key Laboratory of Crops with High Quality and Efficient Cultivation and Security Control, Yunnan Higher Education Institutions, Honghe University, Mengzi 661100, People's Republic of China

4 Environmental Science Department, Institute for Post Graduate of Environment Study, Arish University, Arish 45511, Egypt

5 University of Chinese Academy of Sciences, Beijing 10049, People's Republic of China
Overall endophytic species richness of the sample was 58 taxa while the sample has statistical values of 4.02, 0.97, 0.65 and 16.55 with Shannon's, Simpson, Species evenness and Margalef, respectively. Root tissues were found to be more suitable host for endophytes as compared to leaf and stem tissues. Among these endophytic strains, $88 \%$ can grow on nitrogen-free media, $19 \%$ solubilize phosphate, while 26 and $40 \%$ are positive for production of protease and cellulase, respectively. The results confirm that the medicinal plant Ferula songorica represents an extremely rich reservoir for the isolation of diverged bacteria with potential for growth promoting factors and biologically active compounds including enzymes.

Keywords Ferula songorica · Endophytes - Diversity · Growth promotion - Enzyme

\section{Introduction}

Ferula of the family Umbelliferae is a genus of about 180 species of flowering plants and are native to Mediterranean, central Asia and its adjacent areas (Pimenov and Leonov 2004). Twenty-six of these species are found in Xinjiang Uyghur Autonomous Region (People's Republic of China). Among them, the variety Ferula songorica are distributed in several places of Xinjiang including Hebukesaier, Emin county, Toli county, Yumin county and Tahcheng. Traditionally, they are being utilized for treatments of digestive disorders, rheumatism, headache, dizziness, toothache, etc. (Sun et al. 2013). Excessive excavation for medicinal purposes and man-made destruction during the recent years have, however, severely reduced the number of wild Ferula plants, and have even led to extinction of some varieties. It has now come to a stage that it is almost 
impractical to conserve Ferula plants through artificial cultivation, and therefore, a proper mechanism should be enforced to protect these precious medicinal resources including Ferula songorica.

One such mechanism is to explore the biotechnological potential of the microbial communities residing within the floral resources that are commonly referred to as endophytes. Endophytes have been proven to show positive effects on the host plants by serving as growth promoter, insect and pest repellents, antimicrobial agents against plant pathogens and stress modulators (Ryan et al. 2008; Staniek et al. 2008; Nagabhyru et al. 2013; Rai et al. 2014). A deeper look on endophytes also revealed that they are a source of various bioactive substances that find importance to ecology, medicine, pathology and agriculture (Wang et al. 2008). For example, an endophytic Promicromonospora sp. isolated from Artemisia aпnиа in Yunnan was found to be proteinase and cellulase-producer ( $\mathrm{Li}$ 2010). Endophytic bacterial strains Isoptericola rhizophila, Nitratireductor shengliensis, Paenibacillus lautus and Staphylococcus xylosus associated with halophytes from Xinjiang possess phosphate-solubilizing activities (Huang et al. 2010; Wang 2015).

Of the myriad ecosystems on earth, those with the greatest general biodiversity seem also to have the greatest number and the greatest diversity of endophytes (Strobel et al. 2004). Till date, only a few plants have ever been completely studied in relation to their endophytic biology. The necessity of finding new and beneficial endophytic microorganisms among the wide diversity of plants in different ecosystems is hence considerable. Xinjiang, a typical arid environment, is located in the border areas of northwest China and falls in the center of the Eurasian region. Endophytes adapting this special environment are likely to produce special metabolites. It is, therefore, necessary to explore these special endophytic resources of arid and extremely arid desert habitats. The present study involved the isolation of endophytes associated with medicinal plant Ferula songorica, analyzed the species richness and distribution pattern among the different tissues of the plant. In addition, the plant growth promoting traits and their ability to produce industrial enzymes were studied. The present study, in a small way, will help in conserving the Ferula plant from mass-scale excavation by exploiting the associated endophytes instead of the plant itself.

\section{Materials and methods}

\section{Sample collection and surface sterilization}

Plant samples of Ferula songorica were collected from an alluvial fan located at Hebukesaier, Xinjiang $\left(46^{\circ} 52^{\prime} \mathrm{N}\right.$, $85^{\circ} 55^{\prime} \mathrm{E}$; $1443 \mathrm{~m}$ above sea level) on June 8,2015 . Three samples were randomly collected, each separated by at least $500 \mathrm{~m}$ apart. The plant samples were transported to laboratory in sterile plastic bags and processed within $24 \mathrm{~h}$. The samples were washed in running tap water to remove the clays on the surface of plant tissue and checked for disease symptoms or superficial damage. Symptom-free plant samples were then washed in a water bath sonicator repeatedly until the water become clear. After proper washing, the samples were separated into leaves, stems and roots. Each tissue were separately surface-sterilized by stepwise washing in $75 \%$ ethanol for $1 \mathrm{~min}$, sodium hypochlorite solution for 8 min followed by five rinses in sterile distilled water. Two experiments were carried out to check the effectiveness of sterilization procedures. First, the sterilized-surface tissue was imprinted directly onto yeast extract-malt extract agar (ISP 2), incubated at $30^{\circ} \mathrm{C}$, and checked for microbial growth. Second, the sterile distilled water used in the final rinse was plated onto ISP 2 agar plate and incubated at $30{ }^{\circ} \mathrm{C}$. If no microbial growth occurred on the surface of the medium, the sterilization was considered complete.

\section{Isolation of endophytic bacteria}

Samples were air-dried for 2 days at room temperature and were aseptically homogenized by sterilized commercial blender. Tissues homogenates were then pretreated by one of the following methods:

\section{Method 1}

Directly placed on the selective isolation media (Table 1), and incubated at $30{ }^{\circ} \mathrm{C}$ for $2-8$ weeks.

\section{Method 2}

About $1 \mathrm{~g}$ tissue homogenates was taken to a sterilized tube, added with $9 \mathrm{ml}$ sterile water and thoroughly mixed to give a tissue suspension. The tissue suspension was diluted to a concentration of $10^{-2}$ and $10^{-3}$ followed by plating of $40 \mu \mathrm{l}$ each of the diluted suspension onto the isolation media. The isolation plates were incubated at $30{ }^{\circ} \mathrm{C}$ for $3-12$ weeks.

All experiments were done in duplicate. Pure cultures obtained in the isolation media were grown and maintained in ISP 2 agar.

\section{Genomic DNA extraction}

Enzymatic hydrolysis was used to extract genomic DNAs of all bacteria. About $50 \mathrm{mg}$ of the freshly grown culture 
Table 1 Compositions of the nine different media used for the isolation of endophytic bacteria from plant samples

\begin{tabular}{|c|c|c|}
\hline Medium & Composition $(\mathrm{g} / \mathrm{L})$ & References \\
\hline M1 & $\begin{array}{l}\text { Sodium propionate, } 2 ; \text { L-asparagine, } 1 ;\left(\mathrm{NH}_{4}\right)_{2} \mathrm{SO}_{4}, 0.1 ; \mathrm{KCl}, 0.1 ; \\
\quad \mathrm{MgSO}_{4} \cdot 7 \mathrm{H}_{2} \mathrm{O}, 30 ; \mathrm{FeSO}_{4} \cdot 7 \mathrm{H}_{2} \mathrm{O}, 0.05 ; \text { agar, } 15\end{array}$ & Wang (2015) \\
\hline M2 & Yeast, $0.25 ; \mathrm{K}_{2} \mathrm{HPO}_{4}, 0.5 ; \mathrm{NaCl}, 30$; agar, 15 & Wang (2015) \\
\hline M3 & $\begin{array}{l}\text { Sodium propionate, } 2 ; \text { L-asparagine, } 1 ; \mathrm{NH}_{4} \mathrm{NO}_{3}, 0.1 ; \mathrm{KCl}, 0.1 ; \\
\quad \mathrm{MgSO}_{4} \cdot 7 \mathrm{H}_{2} \mathrm{O}, 0.05 ; \mathrm{FeSO}_{4} \cdot 7 \mathrm{H}_{2} \mathrm{O}, 0.05 ; \mathrm{NaCl}, 30 ; \text { agar, } 15\end{array}$ & Li (2010) \\
\hline M4 & $\begin{array}{l}\text { Cellulose, } 2.5 ; \text { sodium pyruvate, } 2 ; \mathrm{KNO}_{3}, 0.25 ; \text { proline, } 1 ; \mathrm{MgSO}_{4} \cdot 7 \mathrm{H}_{2} \mathrm{O} \text {, } \\
\quad 0.2 ; \mathrm{K}_{2} \mathrm{HPO}_{4}, 0.2 ; \mathrm{CaCl}_{2}, 0.5 ; \mathrm{FeSO}_{4} \cdot 7 \mathrm{H}_{2} \mathrm{O}, 10 \mathrm{mg} ; \mathrm{NaCl}, 30 ; \text { agar, } 15\end{array}$ & Modified from Qin et al. (2009) \\
\hline M5 & $\begin{array}{l}\text { Sodium oxalate, 2; Casein hydrolysate } 0.5 ; \mathrm{KH}_{2} \mathrm{PO}_{4}, 0.3 ; \mathrm{Na}_{2} \mathrm{HPO}_{4} \cdot 12 \mathrm{H}_{2} \mathrm{O} \text {, } \\
\quad 0.5 ; \mathrm{NaCl}, 30 ; \mathrm{ZnSO}_{4} \cdot 7 \mathrm{H}_{2} \mathrm{O}, 0.02 ; \mathrm{CaCl}_{2}, 0.5 ; \text { agar, } 15\end{array}$ & Wang (2015) \\
\hline $\begin{array}{l}\text { M6 } \\
\text { (ISP 5) }\end{array}$ & Glycerol, 10; L-asparagine, $1 ; \mathrm{NaCl}, 30 ; \mathrm{K}_{2} \mathrm{HPO}_{4}, 1 ;$ agar, 15 & Shirling and Gottlieb (1966) \\
\hline M7 & $\begin{array}{l}\text { Added to Sodium propionate, } 1 ; \text { L-asparagine, } 0.2 ; \mathrm{KH}_{2} \mathrm{PO}_{4}, 0.9 ; \mathrm{K}_{2} \mathrm{HPO}_{4} \text {, } \\
\text { 0.6; } \mathrm{MgSO}_{4} \cdot 7 \mathrm{H}_{2} \mathrm{O}, 0.1 ; \mathrm{CaCl}_{2} \cdot 2 \mathrm{H}_{2} \mathrm{O}, 0.2 ; \mathrm{NaCl}, 30 ; \mathrm{KCl}, 0.3 ; \\
\mathrm{FeSO}_{4} \cdot 7 \mathrm{H}_{2} \mathrm{O}, 0.001 ; \text { agar, } 15\end{array}$ & Modified from Qin et al. (2009) \\
\hline M8 & $\begin{array}{l}\text { Sodium propionate, } 2 ; \text { Arginine, } 1 ; \mathrm{NaCl}, 30 ; \mathrm{MgSO}_{4} \cdot 7 \mathrm{H}_{2} \mathrm{O}, 1 ; \mathrm{KH}_{2} \mathrm{PO}_{4}, 0.1 \text {; } \\
\quad \mathrm{FeSO}_{4} \cdot 7 \mathrm{H}_{2} \mathrm{O}, 0.05 ; \text { agar, } 15\end{array}$ & Wang (2015) \\
\hline $\begin{array}{l}\text { M9 } \\
\text { (ISP 4) }\end{array}$ & $\begin{array}{l}\text { Soluble starch, 20; } \mathrm{KNO}_{3}, 1 ; \mathrm{K}_{2} \mathrm{HPO}_{4}, 0.5 ; \mathrm{MgSO}_{4} \cdot 7 \mathrm{H}_{2} \mathrm{O}, 0.5 ; \mathrm{NaCl}, 0.5 \\
\quad \mathrm{FeSO}_{4} \cdot 7 \mathrm{H}_{2} \mathrm{O}, 0.01 ; \text { agar, } 15\end{array}$ & Shirling and Gottlieb (1966) \\
\hline
\end{tabular}

was taken in an autoclaved $1.5 \mathrm{ml}$ Eppendorf tube. To the culture, $480 \mu \mathrm{l}$ TE buffer $(1 \times)$ and $20 \mu$ lysozyme solution $(2 \mathrm{mg} / \mathrm{ml})$ were added. The bacterial suspension was thoroughly mixed and incubated for $2 \mathrm{~h}$ under shaking conditions (160 rpm, $37{ }^{\circ} \mathrm{C}$ ). The mixture was treated with $50 \mu \mathrm{l}$ SDS solution $(20 \%, \mathrm{w} / \mathrm{v})$ and $5 \mu \mathrm{l}$ Proteinase $\mathrm{K}$ solution $(20 \mu \mathrm{g} / \mathrm{ml})$, and kept on a water bath $\left(55^{\circ} \mathrm{C}, 1 \mathrm{~h}\right)$. DNA was then extracted twice with phenol-chloroformisoamyl alcohol $(25: 24: 1 \mathrm{v} / \mathrm{v} / \mathrm{v})$, followed by precipitation with $80 \mu \mathrm{l}$ sodium acetate $(3 \mathrm{~mol} / \mathrm{l}, \mathrm{pH} 4.8-5.2)$ and $800 \mu \mathrm{l}$ absolute ethanol. The resulting DNA precipitate was centrifuged at $4{ }^{\circ} \mathrm{C}(12,000 \mathrm{rpm}, 10 \mathrm{~min})$, washed with $70 \%$ ethanol, and then air-dried. The extracted DNA was resuspended in $40 \mu \mathrm{l}$ sterile Milli-Q water and stored at $-20{ }^{\circ} \mathrm{C}$ for further use.

\section{Sequencing and diversity analysis}

The isolates were subjected to $16 \mathrm{~S}$ rRNA gene sequence analysis for identification at the genus level. Amplification of the 16S rRNA gene was done using the primer pair PAPB (PA: 5'-CAGAGTTTGATCCTGGCT-3'; PB: 5'AGGAGGTGATCCAGCCGCA-3') procured from Sangon Biotech (Shanghai, China). Amplified PCR products were purified and sequenced by Sangon Biotech (Shanghai). The sequences obtained were identified using the EzTaxon-e server database. A sequence similarity of less than $98.65 \%$ from the published database was considered to be a novel strain (Kim et al. 2014). These sequences were then aligned using ClustalX v.2.1 (Larkin et al. 2007). Phylogenetic dendrogram based on the $16 \mathrm{~S}$ rRNA gene sequences was then generated using neighbor-joining method from MEGA 5.1 software package (Tamura et al. 2011).

Diversity of the endophytes in the plant samples was analyzed using the software package PAST 2.03 with relation to the different statistical parameters (Species richness, Shannon's index, Simpson index, Species evenness and Margalef index) (Whittaker 1972; Hammer et al. 2001; Huang et al. 2013).

\section{Growth promotion and enzyme activity}

The endophytic strains were tested for growth promoting traits and production of protease and cellulase. For growth promoting traits, the ability of the strains to solubilize phosphate and fix nitrogen were measured as described by Hu et al. (2012) and Wang (2015). Strain was considered to be able to fix nitrogen if it exhibit growth on both Ashby medium and nitrogen-free culture medium (Hopebio Company, Qingdao, China) (Sen and Sen 1965). Production of protease and cellulase by the endophytic strains were measured as described by Li (2011).

\section{Results}

\section{Effectiveness of surface sterilization}

No microbial growth was observed after 15 days of incubation at $30{ }^{\circ} \mathrm{C}$ when either the sterilized-surface tissue were directly imprinted or the water of final rinse were plated on ISP 2 agar. This indicated that the five-step 
Table 2 Distribution of strains isolated from Ferula songorica

\begin{tabular}{|c|c|c|c|c|c|}
\hline Phyla (3) & Orders (15) & Families (20) & Genera (27) & $\begin{array}{l}\text { Species } \\
(58)\end{array}$ & $\begin{array}{l}\text { Strains } \\
(170)\end{array}$ \\
\hline \multirow[t]{17}{*}{ Actinobacteria } & \multirow[t]{8}{*}{ Micrococcales } & \multirow[t]{3}{*}{ Microbacteriaceae } & Microbacterium & 3 & 9 \\
\hline & & & Curtobacterium & 1 & 1 \\
\hline & & & Agrococcus & 1 & 3 \\
\hline & & \multirow[t]{3}{*}{ Micrococcaceae } & Arthrobacter & 4 & 5 \\
\hline & & & Kocuria & 3 & 11 \\
\hline & & & Micrococcus & 3 & 5 \\
\hline & & Brevibacteriaceae & Brevibacterium & 1 & 1 \\
\hline & & Promicromonosporaceae & Promicromonospora & 2 & 5 \\
\hline & Streptosporangiales & Nocardiopsaceae & Nocardiopsis & 3 & 8 \\
\hline & \multirow[t]{3}{*}{ Corynebacteriales } & \multirow[t]{3}{*}{ Nocardiaceae } & Williamsia & 1 & 4 \\
\hline & & & Rhodococcus & 1 & 1 \\
\hline & & & Nocardia & 1 & 1 \\
\hline & Streptomycetaceae & Streptomycetales & Streptomyces & 5 & 7 \\
\hline & \multirow[t]{2}{*}{ Pseudonocardiales } & \multirow[t]{2}{*}{ Pseudonocardiaceae } & Pseudonocardia & 2 & 2 \\
\hline & & & Saccharopolyspora & 1 & 1 \\
\hline & Propionibacteriales & Nocardioidaceae & Nocardioides & 1 & 1 \\
\hline & Corynebacteriales & Dietziaceae & Dietzia & 2 & 2 \\
\hline \multirow[t]{8}{*}{ Proteobacteria } & Sphingomonadales & Sphingomonadaceae & Sphingomonas & 4 & 22 \\
\hline & Pseudomonadales & Moraxellaceae & Acinetobacter & 2 & 7 \\
\hline & Gammaproteobacteria & Xanthomonadales & Pseudomonas & 1 & 1 \\
\hline & \multirow[t]{2}{*}{ Rhizobiales } & Methylobacteriaceae & Methylobacterium & 2 & 7 \\
\hline & & Rhizobiaceae & Rhizobium & 1 & 14 \\
\hline & Rhodobacterales & Rhodobacteraceae & Paracoccus & 1 & 1 \\
\hline & Burkholderiales & Burkholderiaceae & Ralstonia & 1 & 5 \\
\hline & Caulobacterales & Caulobacteraceae & Brevundimonas & 1 & 23 \\
\hline \multirow[t]{2}{*}{ Firmicutes } & \multirow[t]{2}{*}{ Bacillales } & Paenibacillaceae & Paenibacillus & 1 & 1 \\
\hline & & Bacillaceae & Bacillus & 9 & 22 \\
\hline
\end{tabular}

surface sterilization protocol was effective at inhibiting the growth of epiphytic bacteria. Thus, the subsequent isolates can be considered to be true endophytic bacteria.

\section{Diversity of endophytic bacteria}

The endophytic bacteria isolated in this study displayed considerable diversity. A total of 170 endophytic bacterial isolates representing 58 taxa were isolated from symptomfree, surface sterilized tissues of Ferula songorica. Maximum isolates were obtained from roots ( 88 isolates) while the rest (82) from either leaves or stems. The distribution of the bacterial strains isolated from Ferula songorica among the different phyla are listed in Table 2. The phylum Actinobacteria dominated the endophytic bacterial community in Ferula songorica, representing $62.9 \%$ of the total isolates. The remaining isolates were represented by the phyla Proteobacteria and Firmicutes which constitute 23.5 and $13.5 \%$, respectively. The most predominantly isolated genera among these isolates were Brevundimonas
(23 isolates), Sphingomonas and Bacillus (22 each). While the frequencies of certain genera Microbacterium, Agrococcus, Arthrobacter, Kocuria, Micrococcus, Promicromonospora, Nocardiopsis, Williamsia, Streptomyces, Pseudonocardia, Dietzia, Acinetobacter, Methylobacterium, Rhizobium and Ralstonia falls between 1 and $8 \%$, several isolates were isolated as single strain and these include the genera Curtobacterium, Brevibacterium, Rhodococcus, Nocardia, Saccharopolyspora, Nocardioides, Paracoccus and Paenibacillus. Fig. 1 depicts the dendrogram based on the $16 \mathrm{~S}$ rRNA gene sequences representing a randomly selected strain from each genera associated with Ferula songorica. Among the different isolates, strain SZ4R5S7 exhibited 97.1\% 16S rRNA gene sequence similarity with Nocardioides salsibiostraticola PAMC $26527^{\mathrm{T}}$ indicating that the strain could be new member of the genus Nocardioides.

Table 3 represents the statistical values from PAST analysis indicating bacterial diversity associated with the plant Ferula songorica. Overall species richness of the 


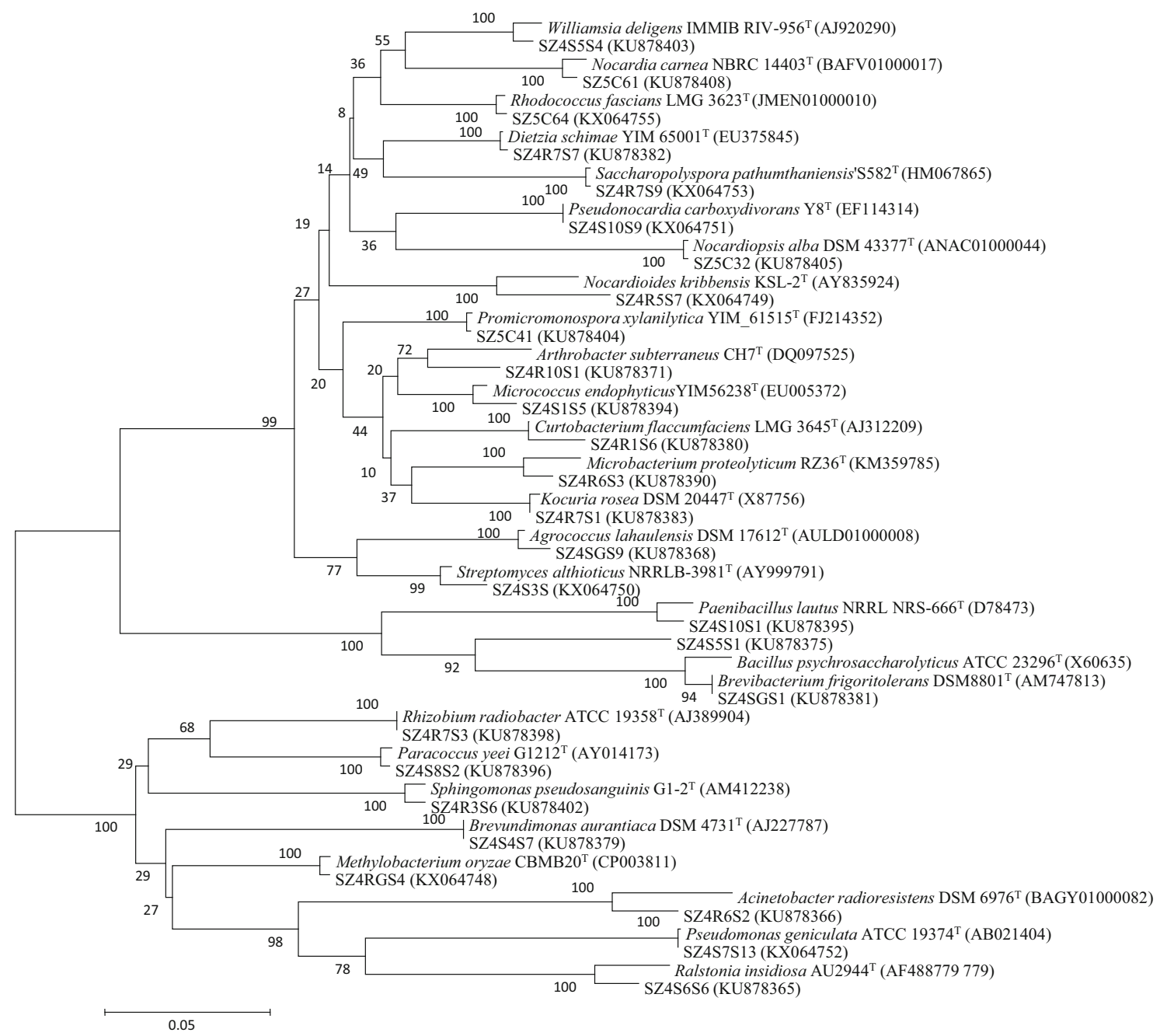

Fig. 1 Neighbour-joining phylogenetic tree based on partial 16S rRNA gene sequences of the representative strains. Numbers in the branches represent the bootstrapping percentage that supports the branch with 1000 bootstrap replications

plant sample was determined to be 58 taxa while the index values according to Shannon, Simpson, Species evenness and Margalef are 4.02, 0.97, 0.65 and 16.55, respectively. All the indices suggest a relatively high diversity of the endophytic bacterium community.

\section{Tissue-specificity of endophytes}

More isolates were obtained from roots than the other two tissues used in the current study (Table 3). Among the different tissues, the distribution of the genera Agrococcus, Brevundimonas, Methylobacterium, Microbacterium, Micrococcus and Rhizobium were higher in roots than in leaves and stems while that of Acinetobacter, Arthrobacter, Kocuria, Ralstonia, Sphingomonas, Streptomyces and Williamsia were more in leaves and stems than roots (Fig. 2). However, some of the genera are restricted to a particular tissue as indicated by the isolation of genera
Brevibacterium, Paenibacillus, Paracoccus, Pseudonocardia and Pseudomonas from leaves and stems, and Curtobacterium, Nocardia, Nocardioides, Promicromonospora, Rhodococcus and Saccharopolyspora from roots. The other three genera were represented at the same rate, for instance, Bacillus, Dietzia and Nocardiopsis (Fig. 2). Based on the PAST analysis (Table 3) species richness was little higher in roots than leaves and stems while species evenness were relatively similar in both the type of tissues ( 0.79 and 0.76 for roots and ground tissues communities, respectively).

\section{Growth promotion and enzyme activity}

Plant growth promoting ability with respect to nitrogen fixation and phosphate solubilization, and enzyme activities with respect to protease and cellulase were tested. It was found that $88 \%$ of the strains have the capacity of fixing nitrogen while $19 \%$ can solubilize phosphate. $26 \%$

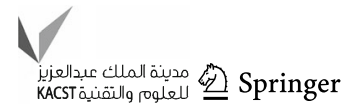


Table 3 Diversity of endophytic strains

\begin{tabular}{lllllrr}
\hline & Individuals & Taxa_S & Shannon_H & Simpson & Evenness & Margalef \\
\hline Leaf and stem & 82 & 40 & 3.42 & 0.96 & 0.76 & 8.85 \\
Root & 88 & 43 & 3.9 & 0.97 & 0.79 & 13.62 \\
Total & 170 & 58 & 4.02 & 0.97 & 0.65 & 16.55 \\
\hline
\end{tabular}

(Shannon H: variety; Simpson: dominance index; Evenness: uniformity; Margalef: abundance)

Fig. 2 Diversity of endophytic strains from Ferula songorica

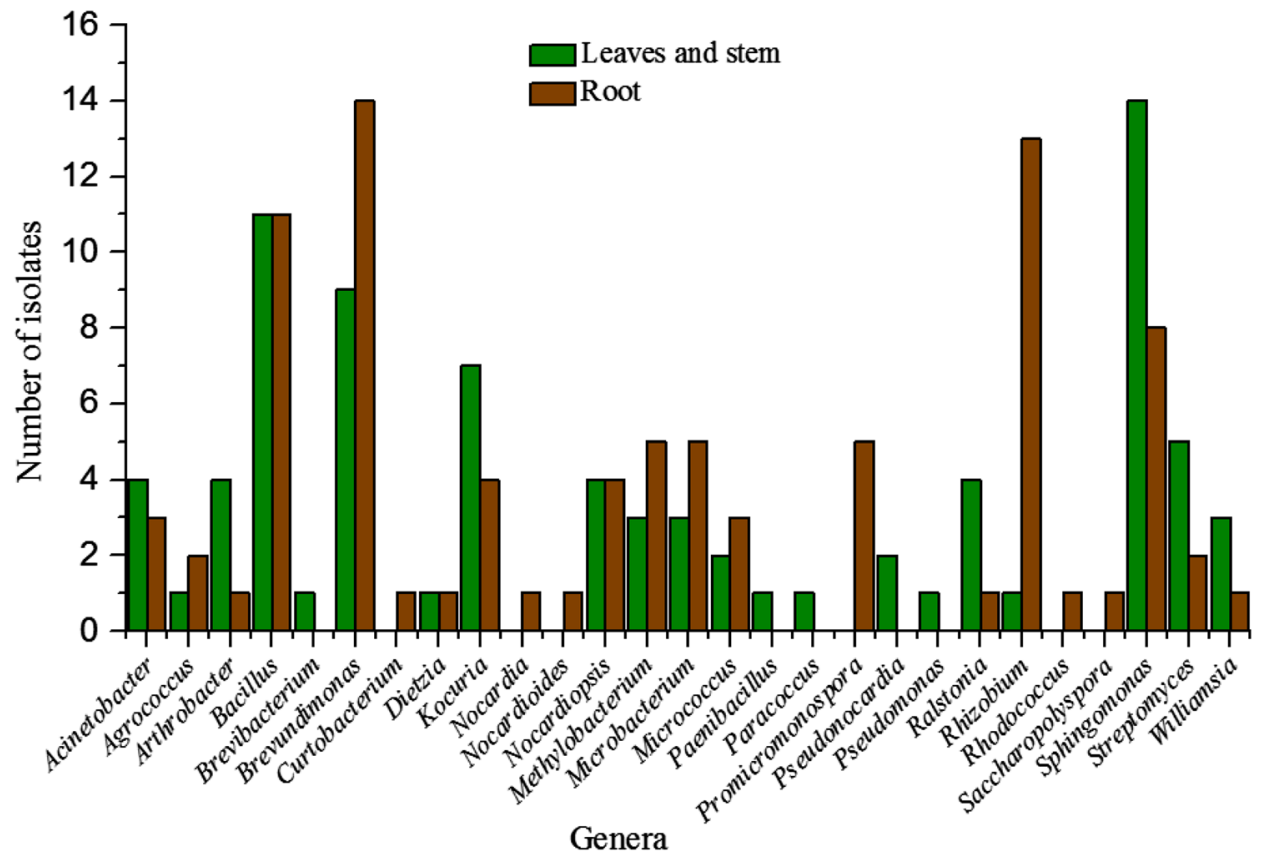

of the strains can produce protease while $40 \%$ are positive for cellulase production. Table 4 list the endophytic strains that are positive for two or more of the activities tested. Strains SZ4R6S2 and SZ4S4S9 showed high ability of phosphate-solubilization followed by strain SZ4R5S4. Except for strains SZ4R7S8, SZ4S8S4 and SZ4S7S13, all strains in Table 4 could fix nitrogen. While strains SZ4S8S4, SZ4S7S13, SZ4R7S10 and SZ4R1S6 are highest protease-producers, strains SZ4S5S1, SZ4R7S10, SZ4R7S8 and SZ4SGS1 are the best cellulase-producing strains among all the endophytes isolated during the present study. Strains SZ4R7S10, SZ4R1S6 and SZ4S6S2 were positive for all the four tests, while strains SZ4S5S1, SZ4S81, SZ4SGS1, SZ4R3S8, SZ4S5S2, SZ4R5S3 and SZ4R3S7 tested positive for three of the activities tested.

\section{Discussion}

Microorganisms are ubiquitous, abundant, and diverse in natural environments, and play important roles in a number of environmental processes. An extensive characterization of diverse population of endophytic bacteria associated with medicinal plants can provide a greater insight into the plant-endophyte interactions, bioactivity and ecological role (Bloemberg and Lugtenberg 2001). Determination of community structure in different tissues is, therefore, essential for subsequent application of bacteria in improvement of site adaptation of plants in extreme environment such as saline soils (Szymańska et al. 2016). In this study, 170 pure bacterial cultures belonging to three phyla, 15 orders, 20 families and 27 genera were isolated using two isolation procedures and nine selective media. The dominant endophytic genera in Ferula songorica belong to Brevundimonas, Sphingomonas and Bacillus. As many members of the genus Brevundimonas were reported from soil (Yoon et al. 2006; Kang et al. 2009; Wang et al. 2012), the predominant isolation of Brevundimonas during the present study may be associated with the theory that most endophytic bacteria come from the surrounding rhizosphere (Long et al. 2010). The genus Sphingomonas have been isolated from plant tissue and some of these species were identified as potential growth regulators of crops (Chen et al. 2014; Khan et al. 2014; Yang et al. 2014; Halo et al. 2015). Bacillus spp. isolated from plant tissue has high richness, and has greater potential as biocontrol agents 
Table 4 Characteristics and enzymatic screening of some representative strains

\begin{tabular}{|c|c|c|c|c|c|}
\hline \multirow[t]{2}{*}{ Strain } & \multirow[t]{2}{*}{ Closest homolog } & \multicolumn{2}{|c|}{ Growth promoting activity } & \multicolumn{2}{|c|}{ Enzyme activity } \\
\hline & & Fix $N$ & Solubilize $\mathrm{P}$ & Protease & Cellulase \\
\hline SZ4R5S4 & Acinetobacter pittii & + & ++ & - & - \\
\hline SZ4R6S2 & & + & +++ & - & - \\
\hline SZ4S5S1 & Bacillus endophyticus & + & - & + & ++ \\
\hline SZ4S81 & Bacillus licheniformis & + & - & + & + \\
\hline SZ4R7S10 & Bacillus safensis & + & + & ++ & ++ \\
\hline SZ4R7S8 & & - & - & + & +++ \\
\hline SZ4R3S14 & Brevundimonas aurantiaca & + & - & - & - \\
\hline SZ4S8S14 & & + & - & - & + \\
\hline SZ4SGS1 & Brevibacterium frigoritolerans & + & - & + & ++ \\
\hline SZ4R1S6 & Curtobacterium flaccumfaciens & + & + & ++ & + \\
\hline SZ4R3S8 & Microbacterium hydrothermale & + & + & - & + \\
\hline SZ4S6S2 & & + & + & + & + \\
\hline SZ4S5S2 & & + & + & - & + \\
\hline SZ4R5S3 & & + & + & - & + \\
\hline SZ4S8S16 & & + & - & - & + \\
\hline SZ4R3S7 & Microbacterium testaceum & + & - & + & + \\
\hline SZ4S8S4 & Micrococcus aloeverae & - & - & +++ & - \\
\hline SZ4S10S1 & Paenibacillus lautus & + & - & - & - \\
\hline SZ4S8S2 & Paracoccus yeei & + & + & - & - \\
\hline SZ4S7S13 & Pseudomonas geniculata & - & - & +++ & - \\
\hline SZ4S7S14 & Rhizobium radiobacter & + & - & - & - \\
\hline SZ4S4S9 & Sphingomonas paucimobilis & + & +++ & - & - \\
\hline
\end{tabular}

The ability to solubilize $\mathrm{P}$, protease and cellulase were represented by halo diameter/colony diameter $(R / r)$ whereby

- (negative), $R / r=1.0 \mathrm{~cm}$ (without halo zone and no enzyme activity); + (weakly positive), $1.0 \mathrm{~cm}<R / r<2.0 \mathrm{~cm}$; ++ (moderately positive), $2.0 \mathrm{~cm} \leq R / r<3.0 \mathrm{~cm} ;+++$ (strongly positive), $R / R \geq 3.0 \mathrm{~cm}$

The ability of fix $\mathrm{N}$ was recorded as "+" if strain grows on both the nitrogen growth media

and plant growth promoters (Kumar et al. 2012). These results were similar with the present study that endophytic bacteria have the promoting ability of nitrogen fixation and phosphate solubilization.

During the present study, more isolates were obtained from root tissues (51.8\% of all isolates) than stem and leaf $(48.2 \%)$. Statistical indices also indicate a higher diversity of endophytes in root than that in stem and leaf. These results were in consistent with that of Chen et al. (2012) and Ma et al. (2013). Similar results were also found in endophytic studies in Cucumis sativus and Oryza sativa (Mano et al. 2007; Mano and Morisaki 2008). The reason for such findings may be related with the bacterial population density in different tissues, which were estimated at $\sim 10^{6}$ cells/g in leaf (Rastogi et al. 2012), while $\sim 10^{8}$ cells/g in rhizosphere (Hardoim et al. 2008).

Jin et al. (2014) analyzed the distribution of endophytic bacteria in various tissues by $16 \mathrm{~S}$ rRNA libraries and recorded that bacterial distribution may be associated with tissue specificity. Endophytic bacteria associated with the plant Ferula songorica during the current study were found to maintain both continuity and specificity in different tissue parts. A total of 13 genera were isolated in both root and ground tissues (leaf and stem), while the rest are specific to either of the two tissues.

There is increasing interest in developing potential biotechnological applications of endophytes for improving phytoremediation and sustainable production of non-food crops for biomass and biofuel production (Ryan et al. 2008). In a related study, Qin et al. (2014) have isolated ACC deaminase-producing endophytic bacteria from a halophytic plant Limonium sinense (Girard) Kuntze for evaluation of plant growth promotion under salt stress conditions. Strains belonging to genera Bacillus, Pseudomonas, Klebsiella, Serratia, Arthrobacter, Streptomyces, Isoptericola and Microbacterium have been shown to exhibit plant growth promoting traits such as phosphate solubilization, IAA production and ACC deaminase activity. During the present study, strains SZ4R6S2 and SZ4S4S9 showed high phosphate-solubilizing activities 
while few other strains have the ability to fix nitrogen and/ or produce cellulase or protease. Strains Z4R7S10, SZ4R1S6 and SZ4S6S2 were positive for all the four activities tested. These results showed that the endophytic bacteria contain rich resources for use as biological control and biofertilizer.

Despite limitation in reflecting the true endophytic microbial diversity by culture-dependent studies (Nadkarni et al. 2009), it has its own advantages in that it gives an insight on the development and utilization of cultured microbial resources (Zhang 2005). Therefore, the use of culture-dependent method has a certain practical significance of reflecting diversity and distribution of endophytic bacteria and their functional role in plant ecological adaptation especially with special habitats such as in arid region of Xinjiang. Another disadvantage with the current method is that the distribution of the endophytes could be related with only the specific time and tissue of the individual plant and thus this method could not analyze the dynamic structure and distribution within the plant. Therefore, isolating the endophytes from different tissues and seasons, and combining them with rhizospheric microorganism is a practical method for providing better knowledge about the endophytic bacterial dynamic diversity.

Acknowledgments This work was supported by National Natural Science Foundation of China (Nos. U1403101 and 31200008) and the West Light Foundation of the Chinese Academy of Sciences. W-J Li was also supported by Hundred Talents Program of the Chinese Academy of Sciences and Guangdong Province Higher Vocational Colleges \& Schools Pearl River Scholar Funded Scheme (2014).

\section{Compliance with ethical standards}

Conflict of interest The authors declare that they have no competing interests.

Open Access This article is distributed under the terms of the Creative Commons Attribution 4.0 International License (http:// creativecommons.org/licenses/by/4.0/), which permits unrestricted use, distribution, and reproduction in any medium, provided you give appropriate credit to the original author(s) and the source, provide a link to the Creative Commons license, and indicate if changes were made.

\section{References}

Bloemberg GV, Lugtenberg BJ (2001) Molecular basis of plant growth promotion and biocontrol by rhizobacteria. Curr Opin Plant Biol 4:343-350

Chen WM, Tang YQ, Mori K, Wu XL (2012) Distribution of culturable endophytic bacteria in aquatic plants and their potential for bioremediation in polluted waters. Aquat Biol 15:99-110

Chen B, Zhang Y, Rafiq MT, Khan KY, Pan F, Yang X, Feng Y (2014) Improvement of cadmium uptake and accumulation in
Sedum alfredii by endophytic bacteria Sphingomonas SaMR12: effects on plant growth and root exudates. Chemosphere 117:367-373

Halo BA, Khan AL, Waqas M, Al-Harrasi A, Hussain J, Ali L, Adnan M, Lee IJ (2015) Endophytic bacteria (Sphingomonas sp. LK11) and gibberellin can improve Solanum lycopersicum growth and oxidative stress under salinity. J Plant Interact 10:117-125

Hammer $\varnothing$, Harper DAT, Ryan PD (2001) PAST: Palaeontological statistics software package of education and data analysis. Palaeontologia Electronica 4:1-9

Hardoim PR, van Overbeek LS, Elsas JD (2008) Properties of bacterial endophytes and their proposed role in plant growth. Trends Microbiol 16:463-471

Hu CJ, Lin L, Shi GY, Wang Q, Wang QS, Li YR (2012) Screening and identification of associative nitrogen fixation bacteria in rhizosphere of sugarcane in Guangxi. Acta Ecologica Sinica $32: 4745-4752$

Huang J, Sheng XF, He LY (2010) Biodiversity of phosphatedissolving and plant growth-promoting endophytic bacteria of two crops. Acta Microbiologica Sinica 50:710-716

Huang B, Harper DAT, Hammer $\varnothing$ (2013) Introduction to PAST, a comprehensive statistics software package for paleontological data analysis. Acta Palaeontologica Sinica 52:161-181

Jin H, Yang XY, Yan ZQ, Liu Q, Li XZ, Chen JX, Zhang DH, Zeng LM, Qin B (2014) Characterization of Rhizosphere and endophytic bacterial communities from leaves, stems and roots of medicinal Stellera chamaejasme L. Syst Appl Microbiol 37:376-385

Kang SJ, Choi NS, Choi JH, Lee JS, Yoon JH, Song JJ (2009) Brevundimonas naejangsanensis sp. nov., a proteolytic bacterium isolated from soil, and reclassification of Mycoplana bullata into the genus Brevundimonas as Brevundimonas bullata comb. nov. Int J Syst Evol Microbiol 59:3155-3160

Khan AL, Waqas M, Kang SM, Al-Harrasi A, Hussain J, Al-Rawahi A, Al-Khiziri S, Ullah I, Ali L, Jung HY, Lee IJ (2014) Bacterial endophyte Sphingomonas sp. LK11 produces gibberellins and IAA and promotes tomato plant growth. J Microbiol 52:689-695

Kim M, Oh HS, Park SC, Chun J (2014) Towards a taxonomic coherence between average nucleotide identity and 16S rRNA gene sequence similarity for species demarcation of prokaryotes. Int J Syst Evol Microbiol 64:346-351

Kumar P, Khare S, Dubey RC (2012) Diversity of bacilli from disease suppressive soil and their role in plant growth promotion and yield enhancement. New York Sci J 5:90-111

Larkin MA, Blackshields G, Brown NP, Chenna R, McGettigan PA, McWilliam H, Valentin F, Wallace IM, Wilm A, Lopez R, Thompson JD, Gibson TJ, Higgins DG (2007) Clustal W and Clustal X version 2.0. Bioinformatics 23:2947-2948

Li J (2010) Resources of endophytic actinobacteria associated with Artemisia annua and their influences on the growth and artemisinin biosynthesis of host plant. Dissertation, Yunnan University

Li L (2011) Diversity and phylogeny of rhizobia and endophytes isolated from Glycyrrhiza spp. nodules in Northwestern China. Dissertation, Northwest A \& F University

Long HH, Sonntag DG, Schmidt DD, Baldwin IT (2010) The structure of the culturable root bacterial endophyte community of Nicotiana attenuata is organized by soil composition and host plant ethylene production and perception. New Phytol 185:554-567

Ma B, Lv X, Warren A, Gong J (2013) Shifts in diversity and community structure of endophytic bacteria and archaea across root, stem and leaf tissues in the common reed, Phragmites australis, along a salinity gradient in a marine tidal wetland of northern China. Antonie Van Leeuwenhoek 104:759-768 
Mano H, Morisaki H (2008) Endophytic bacteria in the rice plant. Microbes Environ 23:109-117

Mano H, Tanaka F, Nakamura C, Kaga H, Morisaki H (2007) Culturable endophytic bacterial flora of the maturing leaves and roots of rice plants (Oryza sativa) cultivated in a paddy field. Microbes Environ 22:175-185

Nadkarni MA, Martin FE, Hunter N, Jacques NA (2009) Methods for optimizing DNA extraction before quantifying oral bacterial numbers by real-time PCR. FEMS Microbiol Lett 296:45-51

Nagabhyru P, Dinkins RD, Wood CL, Bacon CW, Schardl CL (2013) Tall fescue endophyte effects on tolerance to water-deficit stress. BMC Plant Biol 13:127. doi:10.1186/1471-2229-13-127

Pimenov MG, Leonov MV (2004) The Asian Umbelliferae Biodiversity Database (ASIUM) with particular reference to SouthWest Asian taxa. Turk J Bot 28:139-145

Qin S, Li J, Chen HH, Zhao GZ, Zhu WY, Jiang CL, Xu LH, Li WJ (2009) Isolation, diversity and antimicrobial activity of rare actinobacteria from medicinal plants of tropical rain forests in Xishuangbanna, China. Appl Environ Microbiol 75:6176-6186

Qin S, Zhang YJ, Yuan B, Xu PY, Xing K, Wang J, Jiang JH (2014) Isolation of ACC deaminase-producing habitat-adapted symbiotic bacteria associated with halophyte Limonium sinense (Girard) Kuntze and evaluating their plant growth-promoting activity under salt stress. Plant Soil 374:753-766

Rai M, Agarkar G, Rathod D (2014) Multiple applications of endophytic Colletotrichum species occurring in medicinal plants. In: Gurib-Fakim A (ed) Novel plant bioresources: applications in food, medicine and cosmetics. Wiley, Cichester, pp 227-236

Rastogi G, Sbodio A, Tech JJ, Suslow TV, Coaker GL, Leveau JH (2012) Leaf microbiota in an agroecosystem: spatiotemporal variation in bacterial community composition on field-grown lettuce. ISME J 6:1812-1822

Ryan RP, Germaine K, Franks A, Ryan DJ, Dowling DN (2008) Bacterial endophytes: recent developments and applications. FEMS Microbiol Lett 278:1-9

Sen M, Sen SP (1965) Interspecific transformation in Azotobacter. J Gen Microbiol 41:1-6

Shirling ET, Gottlieb D (1966) Methods for characterization of Streptomyces species. Int J Syst Evol Microbiol 16:313-340

Staniek A, Woerdenbag HJ, Kayser O (2008) Endophytes: exploiting biodiversity for the improvement of natural product-based drug discovery. J Plant Interact 3:75-93
Strobel G, Daisy B, Castillo U, Harper J (2004) Natural products from endophytic microorganisms. J Nat Prod 67:257-268

Sun L, Shi SB, Zhu J, Li XJ (2013) Traditional use and modern research review of Ferula in China. Mod Chinese Med $15: 620-626$

Szymańska S, Płociniczak T, Piotrowska-Seget Z, Złoch M, Ruppel S, Hrynkiewicz K (2016) Metabolic potential and community structure of endophytic and rhizosphere bacteria associated with the roots of the halophyte Aster tripolium L. Microbiol Res 182:68-79

Tamura K, Peterson D, Peterson N, Stecher G, Nei M, Kumar S (2011) MEGA5: molecular evolutionary genetics analysis using maximum likelihood, evolutionary distance, and maximum parsimony methods. Mol Biol Evol 28:2731-2739

Wang HF (2015) Study on biodiversity of endophytic bacteria isolated from four Chenopodiaceae halophytes in Xinjiang and evaluation of their growth-promoting function and salt-tolerance ability. Dissertation, Xinjiang Institute of Ecology and Geography, Chinese Academy of Sciences

Wang YY, Han LB, Zeng HM (2008) The summarize about recent research process on Gramineae endophytes symbiosis. Biotechnol Bull 3:33-38

Wang J, Zhang J, Ding K, Xin Y, Pang H (2012) Brevundimonas viscosa sp. nov., isolated from saline soil. Int J Syst Evol Microbiol 62:2475-2479

Whittaker RH (1972) Evolution and measurement of species diversity. Taxon 21:213-251

Yang S, Zhang X, Cao Z, Zhao K, Wang S, Chen M, Hu X (2014) Growth-promoting Sphingomonas paucimobilis ZJSH1 associated with Dendrobium officinale through phytohormone production and nitrogen fixation. Microb Biotechnol 7:611-620

Yoon JH, Kang SJ, Oh HW, Lee JS, Oh TK (2006) Brevundimonas kwangchunensis sp. nov., isolated from an alkaline soil in Korea. Int J Syst Evol Microbiol 56:613-617

Zhang YG (2005) Molecular diversity of soil microbiology in Shanjiangyguna National Natural Reserve. Dissertation, Hunan Agricultural University 